\title{
MANGANESE ELECTRODEPOSITION FROM UREA-RICH ELECTROLYTE
}

\author{
Mladen Vuruna ${ }^{1}$, Mihael Bučko ${ }^{1}$, Ljubica Radović ${ }^{2}$ Jelena B. Bajat ${ }^{3}$ \\ ${ }^{1}$ Military Academy, University of Defense, P.J. Sturma 33, Belgrade, Serbia \\ ${ }^{2}$ Military Technical Institute, Ratka Resanovica 1, Belgrade, Serbia \\ ${ }^{3}$ Faculty of Technology and Metallurgy, University of Belgrade, P.O. Box 3503, Belgrade, Serbia \\ mbucko@tmf.bg.ac.rs
}

\begin{abstract}
Pure manganese coatings were prepared on the steel (AISI 4340) electrode by a non-conventional electrodeposition method, in the presence of $8 \mathrm{~mol} \mathrm{dm}^{-3}$ of urea as a plating additive. The influence of urea on the electrodeposition of Mn was investigated by cyclic voltammetry. The morphology of the coatings was studied by scanning electron microscopy (SEM), and their elemental composition by energy dispersive X-ray spectrometry (EDS). The results showed that the presence of urea in the solution increased the current efficiency for metal reduction for around $20 \%$, and depending on the applied deposition potential, urea may act either as a complexing agent or through the adsorption mechanism. Moreover, urea improves the characteristics of Mn deposits, i.e. their adhesiveness, porosity, compactness, and appearance. Except for oxygen, as part of the Mn corrosion product at the coating surface, no carbon or nitrogen incorporation was detected in the deposits by EDS.
\end{abstract}

Keywords: urea; electrodeposition; Mn coating; morphology

\section{ЕЛЕКТРОДЕПОЗИЦИЈА НА МАНГАН ОД ЕЛЕКТРОЛИТ БОГАТ СО УРЕА}

Приготвени е филм од чист манган врз челична (AISI 4340) електрода со конвенционален метод на електродепозиција во присуство на $8 \mathrm{~mol} \mathrm{dm}^{-3}$ уреа како адитив. Влијанието на уреата врз електродепозицијата на Mn беше испитувано со циклична волтаметрија. Морфологијата на филмот беше студирана со скенирачка електронска микроскопија (SEM), а елементарниот состав со енергетски дисперзивна спектрометрија со X-зраци (EDS). Резултатите покажаа дека присуството на уреа во растворот ја зголемува ефикасноста на струјата со намалување на металот за околу $20 \%$ и во зависност од потенцијалот на депозиција уреата може да дејствува или како комплексирачко средство или преку атсорпционен механизам. Исто така, уреата ги подобрува карактеристиките на депозитите на $\mathrm{Mn}$, т.е. нивната атхезивност, порозност, компактност и изглед. Освен кислород како дел од корозивниот продукт на Mn на површината на филмот, co EDS не беа детектирани инкорпорирани депозити на јаглерод или азот.

Клучни зборови: уреа; електродепозиција; филмови од $\mathrm{Mn}$; морфологија

\section{INTRODUCTION}

The production of pure manganese coating on a steel substrate may offer interesting practical uses, as shown by the following examples. Metallic manganese is used as an alloying element on a large scale in certain types of steel. Coatings of $\mathrm{Mn}$ as well as Mn-alloys with $\mathrm{Cu}, \mathrm{Zn}, \mathrm{Ni}$ or $\mathrm{Co}$ are potentially useful as sacrificial coatings for protecting ferrous substrates against corrosion [1]. Furthermore, it has been recently reported [2] that when Mn coating is obtained on stainless steel, and post-annealed with the flow of nitrogen, the manganese nitride coating is formed, which significantly increases the corrosion resistance of stainless steel in $\mathrm{NaCl}$ medium. In another example [3], the 
Mn and Co layers were sequentially deposited over stainless steel and annealed in oxidizing and inert atmospheres. In this manner, Co and $\mathrm{Mn}$ spinel phase oxides were prepared for application as coatings for interconnectors in solid oxide fuel cells.

The most common way of obtaining the Mn coating is electrochemical deposition - this process has been used for the last 80 years as the final step in the large scale production of metallic Mn from manganese ores [4]. Industrially, manganese is obtained on steel sheets by cathodic reduction of manganese sulfate or chloride, from water solution, along with corresponding ammonium salts. However, the standard reduction potential for $\mathrm{Mn}^{2+} / \mathrm{Mn}$ is very negative $(-1180 \mathrm{mV}$ vs. SHE), so the reduction of $\mathrm{Mn}^{2+}$ to $\mathrm{Mn}$ is always accompanied by hydrogen evolution. Therefore, Mn electrodeposition is still technically very challenging due to a low current efficiency and the formation of rough and dendritic deposits [4].

The use of additives is key in the production of dense high-quality $\mathrm{Mn}$ metals at a high current efficiency, and so, various additives have been investigated for this purpose. Group VI element ( $\mathrm{S}$, Se and $\mathrm{Te}$ ) compounds were reported as the most successful additives which increase the overpotential for hydrogen evolution, improve the leveling effect of the electrolyte and facilitate the crystallization of stable $\alpha$-manganese; unfortunately, however, these compounds have a hazardous effect on the environment and also contaminate the manganese products [5]. Along with S, Se and Te compounds, many other additives, especially organic compounds, such as ammonium thiocyanate [1], carboxylic acid, glycerol, water-soluble polyacrylamide, guar gum and thiourea $[6,7]$, have been tested to improve manganese electrodeposition. However, there is little information about their performance.

In the present study, the influence of urea, $\left(\mathrm{NH}_{2}\right)_{2} \mathrm{CO}$, on manganese electrodeposition from an acidic sulfate solution, was investigated by cyclic voltammetry. The morphology and elemental composition of the Mn deposits were analyzed using scanning electron microscopy (SEM).

Urea was reported as an additive in the electrodeposition of other metals, for instance $\mathrm{Pt}$ arrays [8], $\mathrm{Cr}-\mathrm{Co}$ alloys [9], bright $\mathrm{Cu}$ deposition [10], Zn coating [11], etc. It may act as a leveling agent $[10,11]$ due to the selective adsorption of urea molecules on the specific crystal planes of metal electrode $[8,12]$, but it is also a complexing agent for metal ions [9]. Earlier, a saturated water solution of urea oxalate was used as an electrolyte for the electrodeposition of $\mathrm{Mn}$, as well as metals which were difficult to deposit from aqueous baths (tech- netium and actinium) [13]. Also, urea may be a part of non-aqueous electrolytes for metal electrodeposition, such as an organic solution of $3 \mathrm{~mol} \mathrm{dm}^{-3}$ urea in DMSO [14] or an ionic liquid composed of urea and choline chloride in a molar ratio of 1:2 [15].

A different approach to metal electrodeposition was applied in the present work, as urea was added at a high concentration $\left(8 \mathrm{~mol} \mathrm{dm}^{-3}\right)$ to the aqueous solution, so it did not behave only as an additive, but also as a supporting electrolyte; however, pure urea in water behaves as a weak electrolyte, and with an increase of urea concentration, conductance even slightly falls off [16]. Urea is an economically affordable compound, produced on an industrial scale, and it is very soluble in water $\left(108 \mathrm{~g} / 100 \mathrm{ml}\right.$ at $\left.20^{\circ} \mathrm{C}\right)$. Dissolved in water, it is neither acidic nor alkaline.

\section{EXPERIMENTAL SECTION}

The electrodeposition of Mn coatings and the electrochemical experiments were performed using a sulfate electrolyte containing $1.0 \mathrm{~mol} \mathrm{dm}^{-3}$ $\left(\mathrm{NH}_{4}\right)_{2} \mathrm{SO}_{4}$ and $0.2 \mathrm{~mol} \mathrm{dm}{ }^{-3} \mathrm{MnSO}_{4}, \mathrm{pH} 5.50$. Two types of solutions were prepared to examine the effect of urea on the Mn deposition process: the first solution contained the above ingredients, and in the second solution, urea was added at a concentration of $8 \mathrm{~mol} \mathrm{dm}^{-3}$. The electrolytes were prepared with analytical grade reagents and double distilled water.

The substrates for all experiments were steel (AISI 4340) panels with an active surface area of $3.57 \mathrm{~cm}^{2}$. Prior to each experiment, the steel surface was prepared using abrasive emery papers of the following grades: 600, 1000 and 1200, and then degreased in a saturated solution of $\mathrm{NaOH}$ in ethanol, pickled with $2 \mathrm{~mol} \mathrm{dm}^{-3} \mathrm{HCl}$ for $30 \mathrm{~s}$ and finally rinsed with distilled water.

A three-electrode cell arrangement was used for both the voltammetric studies and $\mathrm{Mn}$ electrodeposition, at the temperature of $25^{\circ} \mathrm{C}$, without stirring. The reference electrode was a saturated calomel electrode (SCE) mounted in a Luggin capillary. All potentials in this paper refer to this electrode. The counter electrode was a platinum plate with surface area of $3 \mathrm{~cm}^{2}$. The working and counter electrodes were separated by a polyester membrane with dimensions of $3 \times 4 \mathrm{~cm}$, with the aim of preventing $\mathrm{Mn}^{2+}$ oxidation products (anodic sludge) to diffuse from anode to the cathodic surface. The initial composition of anodic and cathodic cell compartments was the same, and one aliquot of both was used for coating one sample, after which the solution was discarded. 
The Mn coatings were electrodeposited from solutions with and without urea, galvanostatically at current densities (c.d.s) in the range of $20-90 \mathrm{~mA}$ $\mathrm{cm}^{-2}$, using a PAR M173 galvanostat as the power supply. The deposition time was chosen to obtain layers of $10 \mu \mathrm{m}$ thickness, verified by a coating thickness measuring instrument Dualscope MPOR.

The cyclic voltammetry (CV) experiments were performed with IR correction by using a ZRA Reference 600 potentiostat, Gamry Instruments. The CV curves were carried out by scanning the potential within $-1500 \mathrm{mV}$ to $-400 \mathrm{mV}$ vs. SCE, starting from the rest potential.

Surface morphology of the coatings was examined by scanning electron microscopy, SEM Jeol JSM 6610LV. Chemical analysis of the deposits was performed by an attached energy dispersive $\mathrm{X}$-ray spectrometer (SEM/EDS).

\section{RESULTS AND DISCUSSION}

\subsection{Voltammetric study}

To determine the effect of urea on the reduction of $\mathrm{Mn}(\mathrm{II})$ and $\mathrm{H}_{2} \mathrm{O}$ at steel electrode, we carried out voltammetric studies in the potential range between -1500 and $-400 \mathrm{mV}_{\mathrm{SCE}}$, in different solutions.

Figure 1 presents the $\mathrm{CV}$ curves obtained with a potential scan rate of $20 \mathrm{mV} \mathrm{s}^{-1}$ in $\left(\mathrm{NH}_{4}\right)_{2} \mathrm{SO}_{4}$ solution, containing urea and $\mathrm{MnSO}_{4}$, or without them. Since Mn deposition is always accompanied with hydrogen evolution reaction (HER) [4], the first experiments were carried out in blank solutions without $\mathrm{Mn}^{2+}$ (Fig. 1a). It can be seen that no significant current is recorded at the cathodic scan until $-1070 \mathrm{mV}$, the value corresponding to the onset of HER, and then the current steadily increases with the potential sweep. However, comparison of the two curves in Fig. 1a shows that the starting overpotential for $\mathrm{H}_{2} \mathrm{O}$ reduction is for about $50 \mathrm{mV}$ lower in the presence of urea. The first explanation for this result could be that an additional electrochemical process occurs, i.e. that urea is reduced together with HER. It was reported earlier $[17,18]$ that hydrogen evolution resulted from the electrochemical reduction of urea, according to the reaction:

$$
\mathrm{H}_{2} \mathrm{~N}-\mathrm{CO}-\mathrm{NH}_{2}+\mathrm{e}^{-}=1 / 2 \mathrm{H}_{2(\mathrm{~g})}+\mathrm{H}_{2} \mathrm{~N}-\mathrm{CO}-\mathrm{NH}^{-}
$$

However, these reports relate to urea-based melts and the temperatures from 70 to $140^{\circ} \mathrm{C}$; what is more, urea reduction was indicated by a cathodic current peak [17]. Therefore, we assumed that the reaction (1) did not happen in our case, due to the absence of any peak. Instead, it is assumed that the water reduction process at low overpotential is slightly catalyzed with the addition of urea in the solution, although there are no published data on practical use of urea as an additive in water electrolysis. Nevertheless, it is seen in Figure 1a that the $j-E$ slope for urea-assisted HER process is lower compared to the slope of the curve recorded without urea. As a result, at potentials more negative than $-1390 \mathrm{mV}_{\mathrm{SCE}}$, the water reduction in the solution containing urea is slower compared to the urea-free solution.
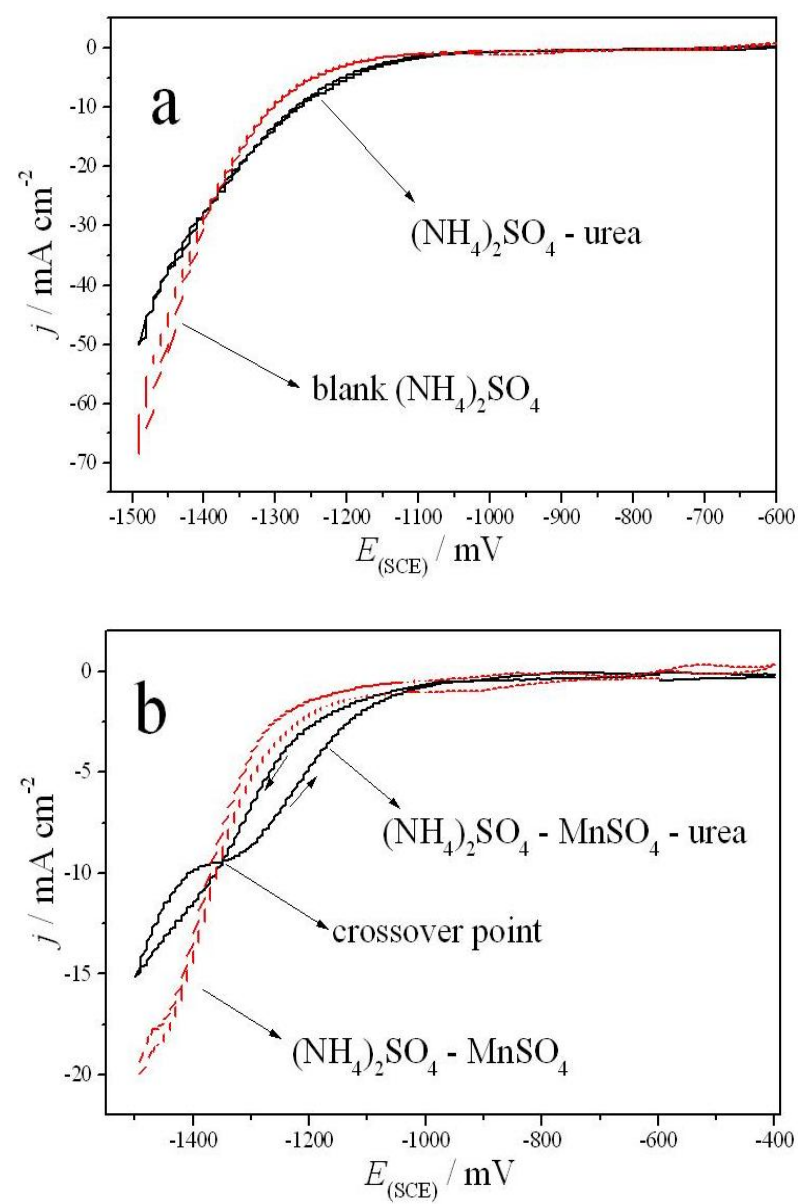

Fig. 1. Influence of urea on cyclic voltammograms recorded on steel electrode at $20 \mathrm{mV} \mathrm{s}^{-1}$, without stirring. The electrolyte composition is denoted in diagrams, where the concentrations are $1 \mathrm{~mol} \mathrm{dm}^{-3}\left(\mathrm{NH}_{4}\right)_{2} \mathrm{SO}_{4}, 0.2 \mathrm{~mol} \mathrm{dm}^{-3} \mathrm{MnSO}_{4}$ and 8 mol dm ${ }^{-3}$ urea.

When $\mathrm{Mn}^{2+}$ ions are present in the solution containing urea (Fig. 1b), the first current onset occurs again at $-1070 \mathrm{mV}$, and the voltammograms recorded towards the negative potentials are the same shape as those observed in the absence of $\mathrm{Mn}^{2+}$ ions (Fig. 1a). This suggests that the $\mathrm{Mn}^{2+} / \mathrm{Mn}$ reduction is masked, and the main process at the working electrode is HER, as in previous cases [19]. However, during the revers- 
ing sweep in the solution with urea, a current crossover between cathodic branches is observed. At a more cathodic potential region than the crossover point, current in the backward sweep is lower than in the forward sweep, probably due to the decreased concentration of $\mathrm{Mn}^{2+}$ ions on the electrode surface as a result of the deposition process, or due to the intensive adsorption of urea molecules. On the other hand, in the potential range that is more positive than the crossover point, the current in the backward sweep is higher than during the forward sweep. This indicates an easier $\mathrm{Mn}^{2+} / \mathrm{Mn}$ reduction and HER process at the freshly formed manganese film, as compared to the bare steel surface electrode [20]. In other words, the crossover of voltammogram branches in the solution with urea gives evidence that this compound is beneficial for manganese nucleation and growth [20].

It is clear from Figures $1 \mathrm{a}$ and $1 \mathrm{~b}$ that at the potentials more negative than $-1390 \mathrm{mV}$, the cathodic current density of the voltammograms recorded in the presence of urea is lower than that of the curves recorded without urea. This behavior is in accordance with the voltammetric investigation of the majority of organic additives (for example $[1,10])$, where a supplementary overvoltage for both the HER and metal ion reduction is usually observed, due to an adsorbed layer of additive molecules on the electrode surface [21].

Contrary, at potentials more positive than $-1390 \mathrm{mV}$ in the case of urea addition, as shown in Figure 1, both reduction processes are facilitated. To explain this result, an analogy with chromium electrodeposition can be made. According to the literature, urea has been used as a complexing agent in the reduction of $\mathrm{Cr}$ (III) ions to $\mathrm{Cr}$, in order to increase current efficiency. Namely, it is known that $\left[\mathrm{Cr}\left(\mathrm{H}_{2} \mathrm{O}\right)_{5}\right]^{2+}$ and $\left[\mathrm{Cr}\left(\mathrm{H}_{2} \mathrm{O}\right)_{6}\right]^{3+}$ species are quite stable and inert, so they are heavily reduced at the cathode, but urea forms active $\left[\mathrm{Cr}(\text { urea })_{n}\left(\mathrm{H}_{2} \mathrm{O}\right)_{6-n}\right]^{3+}$ complexes which are reduced more easily [22, 23]. Therefore, the observed influence of urea on Mn reduction in this work could be explained through the formation of complex salts like [Mn(urea $\left.)_{3}\left(\mathrm{H}_{2} \mathrm{O}\right)_{6-3}\right]^{2+}$ and $\left[\mathrm{Mn}(\text { urea })_{6}\right]^{2+}$ which are well documented [24]. On the contrary, the role of $8 \mathrm{~mol} \mathrm{dm}^{-3}$ urea in increasing the rate of HER is not easy to explain and it requests further research, also because we could not find any report regarding the catalytic or inhibiting activity of urea towards water reduction. Nevertheless, the explanation could be the complexation of water molecules as for the $\mathrm{Mn}^{2+}$ ions, because $\mathrm{H}_{2} \mathrm{O}$-urea complex species have been also reported [25].
Very weak oxidation peaks are observed in the anodic branch of CV curves (Figs. 1a and 1b). Similar behavior has been reported in [1], where the lack of peak related to manganese dissolution was attributed to the instability of the manganese deposits, which are easily dissolved in acidic media. In order to obtain more intensive peaks which can be distinguished from the baseline, higher scan rates may be applied [26], as shown in Figure 2.
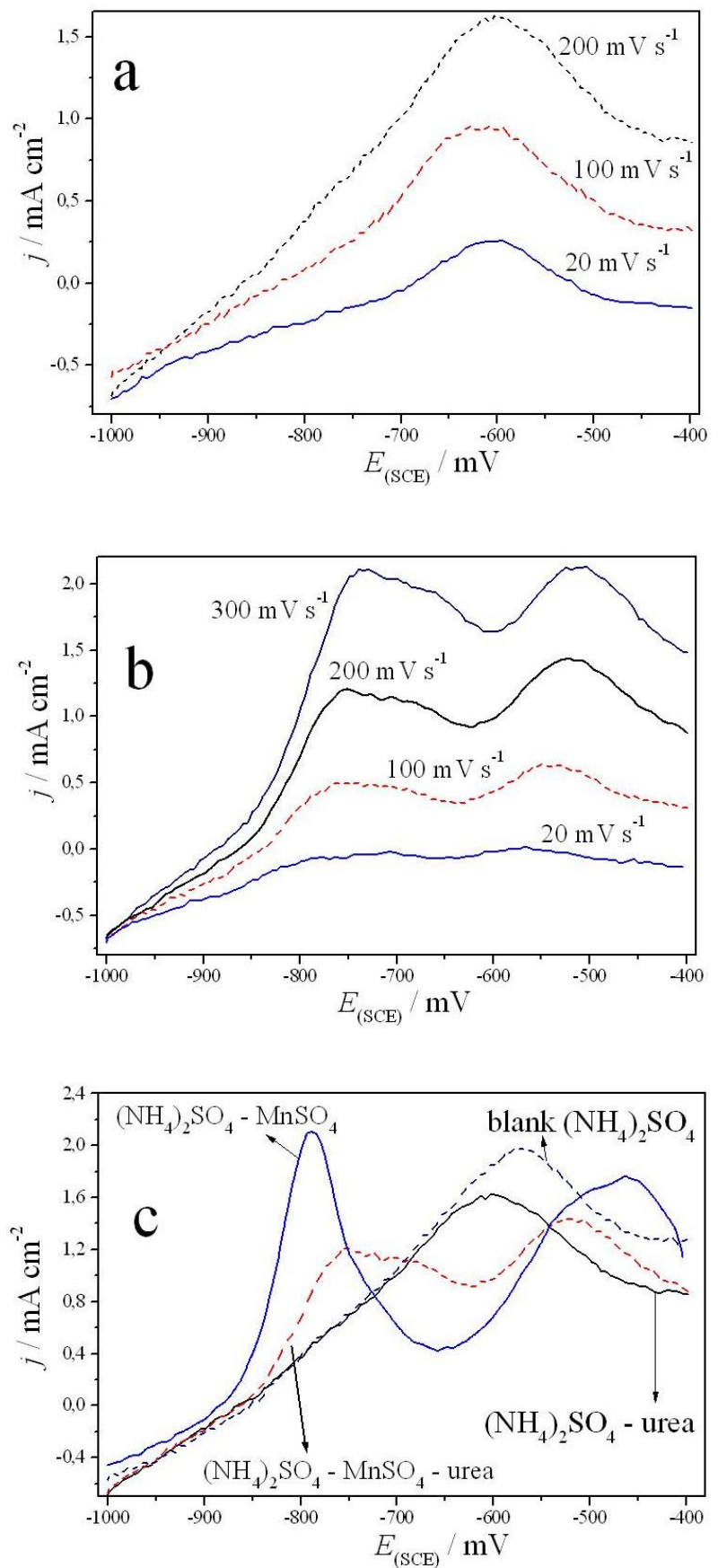

Fig. 2. Anodic part of voltammograms (a) obtained at various scan rates in $\left(\mathrm{NH}_{4}\right)_{2} \mathrm{SO}_{4}$-urea solution; (b) obtained at various scan rates in $\left(\mathrm{NH}_{4}\right)_{2} \mathrm{SO}_{4}-\mathrm{MnSO}_{4}$-urea solution; and (c) obtained at $200 \mathrm{mV} \mathrm{s}^{-1}$ in four different solutions, on a steel electrode without stirring 
The voltammograms obtained in $\mathrm{Mn}^{2+}$-free solution, with or without urea, show one anodic peak at around $-600 \mathrm{mV}$ (Fig. 2a), which can be attributed to the pre-oxidation or pre-passivation of steel to form the $\mathrm{Fe}(\mathrm{OH})_{2}$ deposit layer according to the reaction [27]:

$$
\mathrm{Fe}+2 \mathrm{H}_{2} \mathrm{O}=\mathrm{Fe}(\mathrm{OH})_{2}+2 \mathrm{H}^{+}+2 \mathrm{e}^{-}
$$

On the contrary, when $\mathrm{Mn}^{2+}$ ions are added to the solution, two separate anodic peaks appear (Fig. 2b), which may correspond to the dissolution of manganese (at around $-750 \mathrm{mV}$ ) and probably its oxides and/or hydroxides (at around $-500 \mathrm{mV}$ ), as already reported in an earlier work [28].

As a summary, Figure 2c illustrates the anodic part of voltammograms obtained in four different solutions, at $200 \mathrm{mV} \mathrm{s}^{-1}$. Although the peak positions slightly evolve according to the solution composition, generally, one may conclude that the voltammograms in $\mathrm{Mn}^{2+}$-free solution show one peak corresponding to the steel corrosion, while those obtained with $\mathrm{Mn}^{2+}$ ions exhibit two peaks related to $\mathrm{Mn}$ dissolution. It is also clear in both cases that the peak intensity is lower when urea is added to the solution, i.e. urea in this case acts as a dissolution inhibitor, which is in accordance with the previous literature [29]. For this reason, it is not feasible to estimate a current efficiency for Mn deposition by calculating the total charge of the anodic and cathodic current peaks in Figures 1 and 2.

In order to better understand the influence of urea on both $\mathrm{Mn}^{2+}$ reduction and HER, a current efficiency $(C E)$ for metal deposition at various current densities was calculated from the mass gain of the cathode, and the results are shown in Figure 3. In both plating baths, the manganese electrodeposit did not cover the entire substrate surface for current densities lower than $20 \mathrm{~mA} \mathrm{~cm}$. At higher c.d.s, the current efficiency of the Mn electrodeposition reaction steadily increased to $65 \%$ (without urea) and $84 \%$ (with urea) at $40 \mathrm{~mA} \mathrm{~cm}$, and it was on a high level at $c . d$. values up to $60 \mathrm{~mA} \mathrm{~cm}^{-2}$. At the c.d.s higher than $60 \mathrm{~mA} \mathrm{~cm}^{-2}$, the current efficiency decreased, reaching a value of $22 \%$ for $90 \mathrm{~mA} \mathrm{~cm}^{-2}$ in the bath without urea. Such a decrease in current efficiency after reaching certain critical c.d. is a consequence of limited diffusion of $\mathrm{Mn}^{2+}$ species to the cathode, so any further increase in $c . d$. above 60 $\mathrm{mA} \mathrm{cm}{ }^{-2}$ only increases the HER [30].

The $C E$ dependence on c.d., characterized with maximum at certain $c . d$. range, as observed in Figure 3, is typical of Mn electrolysis from aqueous solution, since a HER may occur at a more positive potential than $\mathrm{Mn}^{2+}$ reduction. However, the posi- tion of $C E$ maximum varies with substrate type, plating bath composition, and temperature [4].

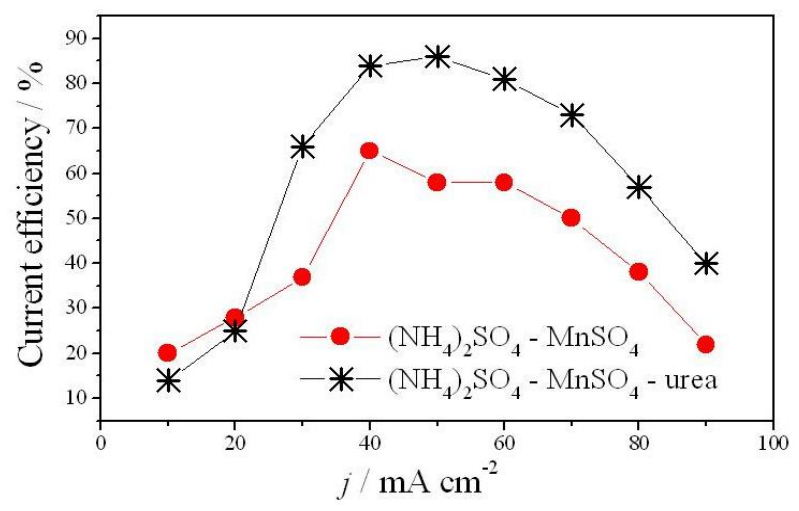

Fig. 3. Current efficiency versus current density for $\mathrm{Mn}$ deposition with and without urea in the plating bath.

Figure 3 shows higher plating efficiency for an urea containing bath, which is probably related to the formation of active $\mathrm{Mn}$ (II)-urea complexes, since the complexation may enhance metal deposition in several ways. Firstly, it is seen that the difference in $C E$ between the non-urea and the urea bath is more expressed at higher c.d.s, i.e. at higher rates of both $\mathrm{Mn}^{2+}$ reduction and HER. When the HER exceeds a certain rate, the $p H$ increase in the near cathode layer enables the formation of $\mathrm{Mn}(\mathrm{OH})_{2}$ species and its oxidation product $\mathrm{MnO}(\mathrm{OH})_{2}$, and they may inhibit $\mathrm{Mn}$ reduction and decrease $C E$ [19]. Therefore, it may be proposed that Mn-urea complexes prevent the formation of $\mathrm{Mn}$ hydroxo-compounds and increase the $C E$ in this manner. Furthermore, it was suggested that at high c.d.s, when diffusion to the cathode becomes an important step in the reduction mechanism, some ligands may improve $\mathrm{Mn}$ reduction if the diffusion coefficient of $\left[\mathrm{MnL}_{\mathrm{n}}\left(\mathrm{H}_{2} \mathrm{O}\right)_{6-\mathrm{n}}\right]^{2+}$ species is higher than for the $\left[\mathrm{Mn}\left(\mathrm{H}_{2} \mathrm{O}\right)_{6}\right]^{2+}$ species [30]. Finally, urea as an organic molecule, may increase the plating $C E$ by selectively adsorbing on active sites of the growing deposit, thus preventing aggregation of the newly generated $\mathrm{Mn}$ atoms into dendrites [8], as confirmed by SEM characterization in the following section.

\subsection{Effect of urea on the morphological properties of Mn coating}

The effect of urea in the plating electrolyte on the formation and distribution of the manganese agglomerates formed on the steel substrate was investigated by SEM. Microphotographs were taken for deposits obtained at c.d.s in the range of 40$60 \mathrm{~mA} \mathrm{~cm}{ }^{-2}$, which were the ones with the highest current efficiency. The time of deposition was adjusted to produce $10 \mu \mathrm{m}$ thick coatings. 

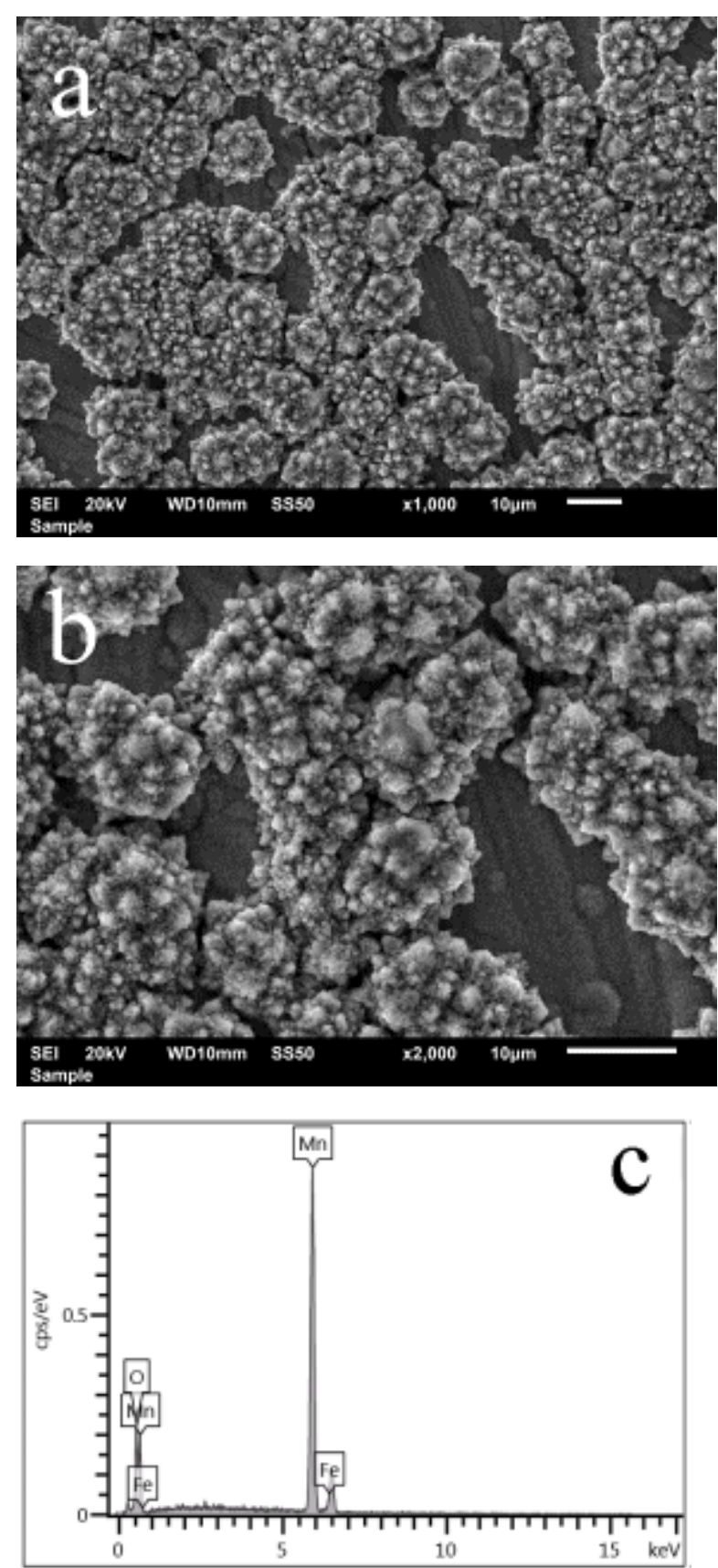

Fig. 4. The SEM microphotographs (a, b) and the EDS diagram (c) for manganese coating electrodeposited at $40 \mathrm{~mA} \mathrm{~cm}^{-2}$ from the bath without urea

Figures $4 \mathrm{a}$ and $4 \mathrm{~b}$ show the deposit obtained at $40 \mathrm{~mA} \mathrm{~cm}^{-2}$ in the absence of urea. The manganese growth produces a surface with high roughness on the macroscopic scale and the formation of porous deposits. The flower-like clusters, having different sizes, are dispersed all over the steel surface, and pores between them even reach the substrate. When a longer deposition time was applied, to make coatings thicker than $10 \mu \mathrm{m}$, the deposits peeled off.

In contrast, in the presence of urea (Figs. 5 $\mathrm{a}, \mathrm{b}$ and $6 \mathrm{a}, \mathrm{b}$ ), non-dendritic coatings with good adherence were obtained. The growth of Mn crystallites perpendicular to the surface was inhibited and they spread across the surface as smooth ovalshaped agglomerates to produce deposits which were rather flat and dense on the microscopic scale. Therefore, these results suggest that urea functioned as a leveling agent. However, there are still small differences between the coatings obtained at different $c . d$.s in the presence of urea. The agglomerates formed at higher $c . d$ (Fig. 6) are less uniform in size, and they possess spot-like pores, probably due to the more intensive hydrogen evolution at the growing deposit [31]. Also, the coatings obtained at $40 \mathrm{~mA} \mathrm{~cm}$ were white and semibright in appearance, while those produced at higher $c . d$ were dull, as affirmed by the naked eye.
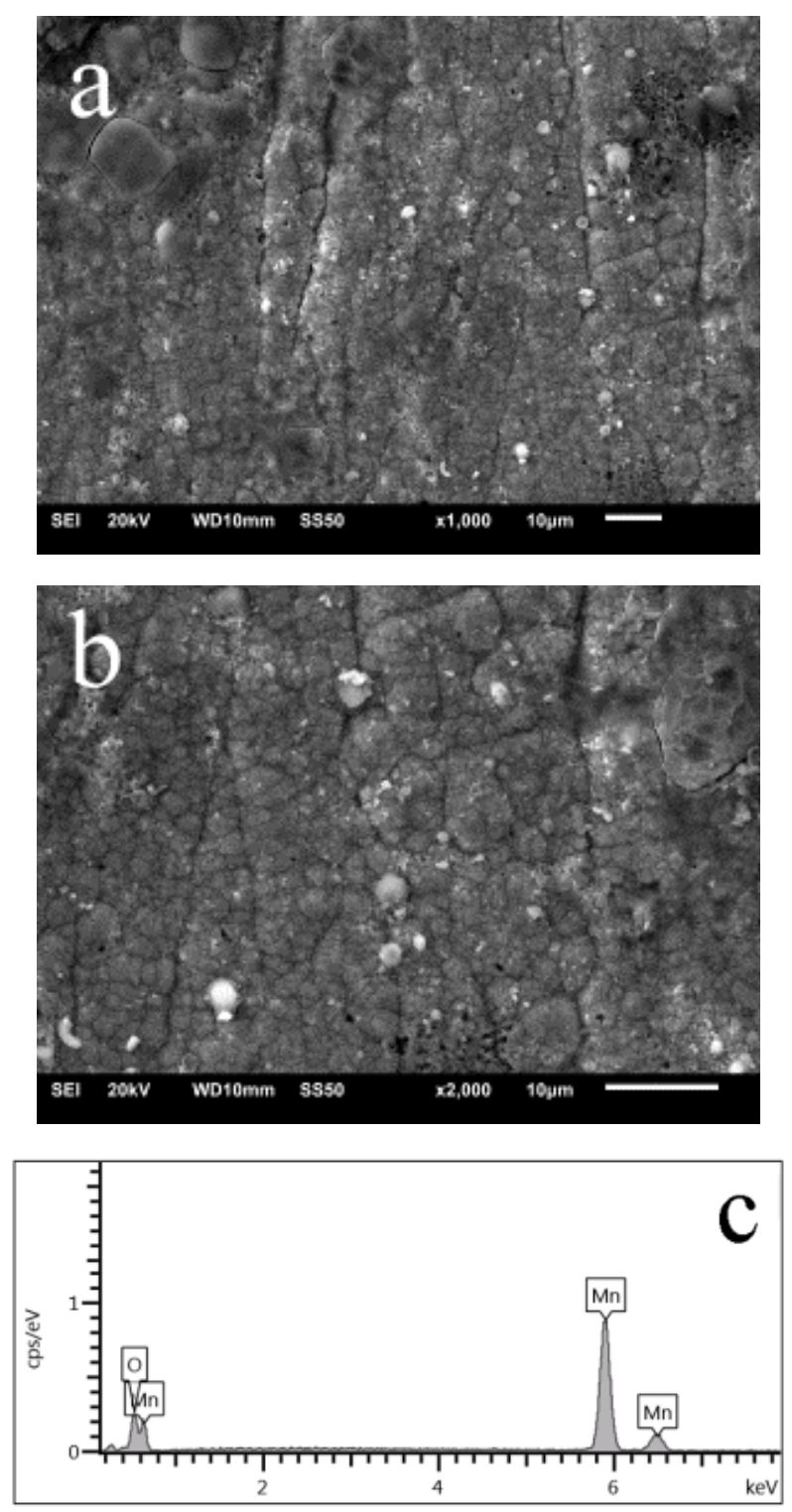

Fig. 5. The SEM microphotographs (a, b) and the EDS diagram (c) for manganese coating electrodeposited at $40 \mathrm{~mA} \mathrm{~cm}{ }^{-2}$ from the bath with urea 

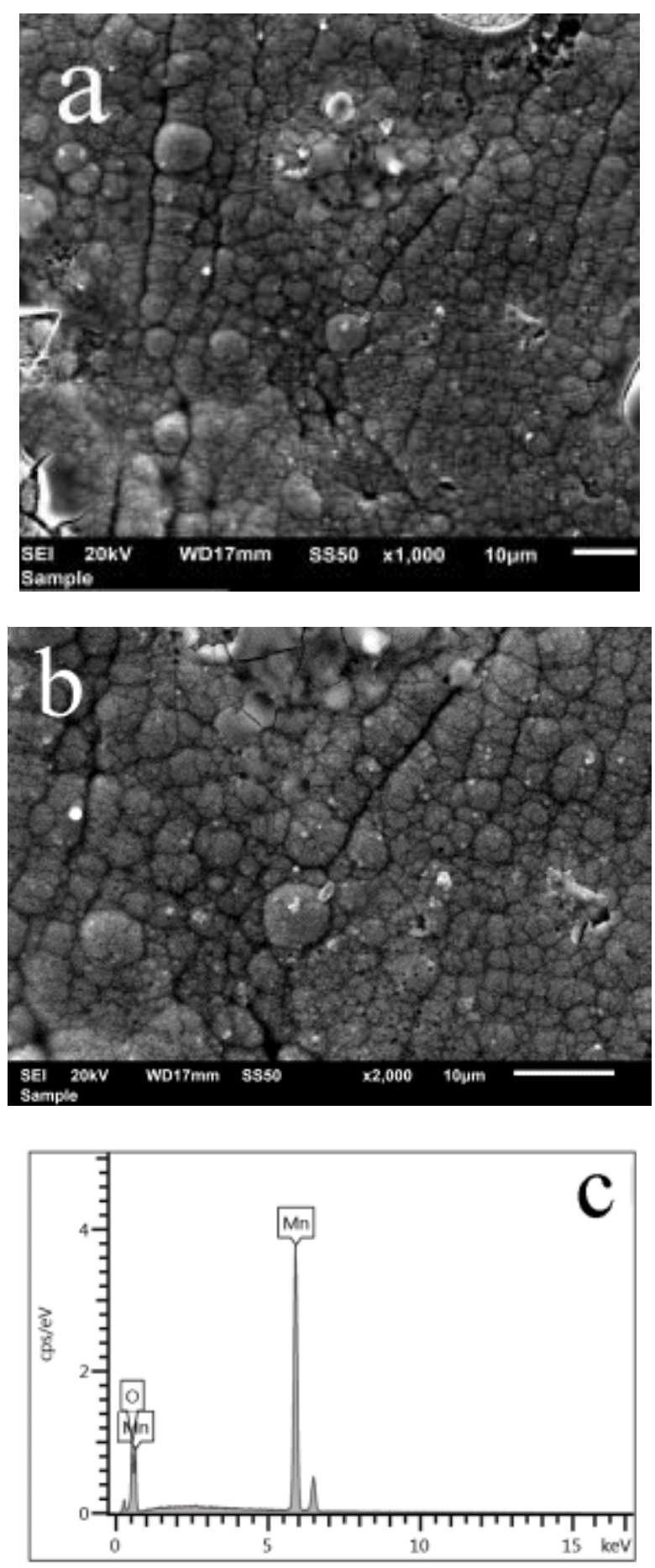

Fig. 6. The SEM microphotographs (a, b) and the EDS diagram (c) for manganese coating electrodeposited at $60 \mathrm{~mA} \mathrm{~cm}{ }^{-2}$ from the bath with urea

To sum up, the SEM analysis provides evidence that the addition of $8 \mathrm{~mol} \mathrm{dm}^{-3}$ urea in the plating electrolyte improves the morphological properties of Mn deposits, such as increased adhesion, smoothness, uniform coverage, and white appearance. These differences might be ascribed to the adsorption action of urea molecules at the active sites of Mn coating $[8,10]$ and to the change in the electrodeposition mechanism caused by the Mn-urea complex species formation [30]. In a commercial manganese production, the Mn deposit gradually becomes rougher and more dendritic with increasing deposition time, resulting in a lower current efficiency. Therefore, the Mn electrolysis industry is constantly seeking new additives which would ensure smooth and compact deposition and have a minimum contamination of the $\mathrm{Mn}$ coating [6].

\subsection{Effect of urea on the chemical composition of Mn coating}

In order to examine the purity of electroplated manganese, the elemental composition of the coatings was determined by EDS. Typical EDS diagrams for deposits obtained at different c.d.s, with or without urea, are shown in Figs. 4-6 together with SEM images, and the data are presented in Table 1. Besides Mn, around 6 wt. \% of oxygen was detected at the surface of all coatings, but this is a regular observation for manganese, because a layer of manganese oxides and/or hydroxides $(30$ to $50 \mathrm{~nm}$ ) naturally forms on electrodeposited Mn coatings [1, 30]. It is known from earlier research $[19,30,32]$ that much higher oxygen content (60 wt. \% and more) is present in Mn deposits when Mn oxides/hydroxides are included in the coating during the electrodeposition process. Therefore, it may be concluded that under the conditions applied in the present work, oxygen-free Mn deposits are obtained.

Table 1

EDS elemental composition of manganese coatings electrodeposited at different current densities

\begin{tabular}{lccc}
\hline $\begin{array}{l}\text { Deposition } \\
\text { conditions }\end{array}$ & wt. \% Mn & wt. \% O & wt. \% Fe \\
\hline $\begin{array}{l}40 \mathrm{~mA} \mathrm{~cm}^{-2} \\
\text { without urea }\end{array}$ & 92 & 6 & 2 \\
\hline $\begin{array}{l}40 \mathrm{~mA} \mathrm{~cm}^{-2} \\
\text { with urea }\end{array}$ & 94 & 6 & 0 \\
\hline $\begin{array}{l}60 \mathrm{~mA} \mathrm{~cm} \text { c }^{-2} \\
\text { with urea }\end{array}$ & 93 & 7 & 0 \\
\hline \hline
\end{tabular}

Nevertheless, Table 1 shows that at the sample deposited in urea-free electrolyte at $40 \mathrm{~mA}$ $\mathrm{cm}^{-2}$, EDS detected around 2 wt. \% Fe from the substrate, despite the fact that the coatings were 10 $\mu \mathrm{m}$ thick. This finding is in agreement with SEM microphotograph (Fig. 4a) which has shown that the Mn coating was porous and the pores reached to the substrate. 
It should be emphasized in this section that no carbon or nitrogen was detected in the deposits, although a high concentration of urea was involved in the electrodeposition process. This is in agreement with the report from B. Bozzini et al., who thoroughly investigated the influence of thiourea, $\left(\mathrm{NH}_{2}\right)_{2} \mathrm{CS}$, on the electrodeposition of $\mathrm{Zn}-\mathrm{Mn}$ alloys [33]. Thiourea differs from urea only in a sense that the carbon atom is double-bonded to sulfur, instead of an oxygen atom, and the cathodic reduction of thiourea gives urea along with $\mathrm{Zn}^{2+}$ and $\mathrm{Mn}^{2+}$ reduction. However, the XPS analysis in this research [33] did not show the presence of $S$, $\mathrm{C}$ or $\mathrm{N}$ in the deposits. On the contrary, $\mathrm{Cr}$ deposits obtained by $\mathrm{Cr}(\mathrm{III})$ electrodeposition in the presence of urea, may contain considerable amounts of organo-metallic compounds with amide- and carboxylic-groups, chromium carbides or nitrides, as a consequence of the reduction of the organic ligand from the inner coordination sphere of the chromium complex [9]. Therefore, although it was concluded in the electrochemical section that urea enhances $\mathrm{Mn}$ and $\mathrm{Cr}$ deposition in a similar way, the elemental analysis of the deposits proves that there are still differences in the urea-assisted reduction mechanism of these two metals.

\section{CONCLUSION}

This work offers a new method for manganese electrodeposition from aqueous solution, where an organic substance is added in high concentrations $\left(8 \mathrm{~mol} \mathrm{dm}^{-3}\right)$ in order to improve the deposition process and deposit characteristics. Urea was chosen as a high-concentration additive, having already been used as an ionic liquid and organic solution in metal electrolysis. Electrochemical analysis has shown that at lower overpotentials, urea facilitates both the hydrogen evolution reaction and $\mathrm{Mn}^{2+}$ reduction, probably through the complexation phenomenon, while at potentials more negative than $-1390 \mathrm{mV}_{\mathrm{SCE}}$, these processes are inhibited as a result of urea adsorption on the working electrode. However, it was pointed out that the current efficiency for metal deposition is higher in average for $20 \%$ in the urea-containing bath, and the highest efficiency was measured in the current density range between 40 and $60 \mathrm{~mA} \mathrm{~cm}$.

The most distinct effect of urea was observed by SEM analysis of the coatings' morphology, where it was shown that without the additive, a porous coating is formed, with flower-like agglomerates which are detached at longer deposition times. In contrast, the Mn samples obtained with urea are smooth, compact, with oval-shaped ag- glomerates, and for the deposition current density of $40 \mathrm{~mA} \mathrm{~cm}^{-2}$ have white and semi-bright appearance. The chemical analysis shows that Mn deposits formed in this work, regardless of the urea presence in the plating electrolyte, do not contain inclusions with oxygen, carbon or nitrogen atoms.

Acknowledgements. This research was financed by the Ministry of Education, Science and Technological Development of the Republic of Serbia through the Project Nos. III 45019 and TR 36050.

\section{REFERENCES}

[1] P. Díaz-Arista, G. Trejo, Electrodeposition and characterization of manganese coatings obtained from an acidic chloride bath containing ammonium thiocyanate as an additive, Surf. Coat. Technol., 201, 3359-3367 (2006).

[2] A. R. Grayeli-Korpi, H. Savaloni, M. Habibib, Corrosion inhibition of stainless steel type AISI 304 by $\mathrm{Mn}$ coating and subsequent annealing with flow of nitrogen at different temperatures, Appl. Surf. Sci., 276, 269-275 (2013).

[3] R. Pinto, M. J. Carmezim, M. F. Montemor, Electrodeposition and isothermal aging of Co and Mn layers on stainless steel for interconnectors: Initial stages of spinel phase formation, J. Power Sources, 255, 251-259 (2014).

[4] A. Sulcius, E. Griskonis, K. Kantminiene, N. Zmuidzinaviciene, Influence of different electrolysis parameters on electrodeposition of $\gamma$ - and $\alpha-\mathrm{Mn}$ from pure electrolytes - review with special reference to Russian language literature, Hydrometallurgy, 137, 33-37 (2013).

[5] Y. Sun, X. Tian, B. He, C. Yang, Z. Pi, Y. Wang, S. Zhang, Studies of the reduction mechanism of selenium dioxide and its impact on the microstructure of manganese electrodeposit, Electrochim. Acta, 56, 8305-8310 (2011).

[6] J. Lu, D. Dreisinger, T. Glück, Manganese electrodeposition - A literature review, Hydrometallurgy, 141, 105-116 (2014).

[7] Q. Wei, X. Ren, J. Du, S. Wei, S. Hu, Study of the electrodeposition conditions of metallic manganese in an electrolytic membrane reactor, Miner. Eng., 23, 578-586 (2010).

[8] M. Zhang, J. J. Lv, F. F. Li, N. Bao, A. J. Wang, J. J. Feng, D. L. Zhou, Urea assisted electrochemical synthesis of flower-like platinum arrays with high electrocatalytic activity, Electrochim. Acta, 123, 227232 (2014).

[9] S. Survilienè, V. Jasulaitienè, A. Češūnienè, A. LisowskaOleksiak, The use of XPS for study of the surface layers of $\mathrm{Cr}-\mathrm{Co}$ alloy electrodeposited from $\mathrm{Cr}$ (III) formateurea baths, Solid State Ionics, 179, 222-227 (2008).

[10] L. Bonou, M. Eyraud, R. Denoyel, Y. Massiani, Influence of additives on $\mathrm{Cu}$ electrodeposition mechanisms in acid solution: direct current study supported by non- 
electrochemical measurements, Electrochim. Acta, 47 4139-4148 (2002).

[11] K. Boto, Electrodeposition Surf. Treat., Organic additives in zinc electroplating, 3, 77-95 (1975).

[12] R. N. Emerson, C. J. Kennady, S. Ganesan, Effect of organic additives on the magnetic properties of electrodeposited CoNiP hard magnetic films, Thin Solid Films, 515, 3391-3396, (2007).

[13] A. Rane, K. Bhatki, Electrodeposition of carrier-free manganese-54, technetium-99 and actinium-288 from aqueous baths, Int. J. Appl. Radiat. Is., 24, 385-389 (1973).

[14] G. Li, Q. Ke, G. Liu, Y. Tong, Studies on the electrochemical preparation of $\mathrm{MgCeCo}$ alloy thin films on $\mathrm{Cu}$ substrates in urea-DMSO system, Mater. Lett., 60 2611-2616 (2006).

[15] M. Harati, D. Love, W. Lau, Z. Ding, Preparation of crystalline zinc oxide films by one-step electrodeposition in Reline, Mater. Lett., 89, 339-342 (2012).

[16] T. Tsuda, T. Tomioka, C. Hussey, Physicochemical properties of highly conductive urea-EtMeImCl melts, Chem. Commun., 25, 2908-2910 (2008).

[17] S. L. Wang, J. B. Lin, Q. Y. Cai, Y. Zhang, Electrodeposition of Co-La alloy films in urea melt and their performances, J. Alloy. Comp., 450, 142-147 (2008).

[18] M. Bučko, J. Rogan, B. Jokić, M. Mitrić, U. Lačnjevac, J. B. Bajat, Electrodeposition of $\mathrm{Zn}-\mathrm{Mn}$ alloys at high current densities from chloride electrolyte, J. Solid State Electrochem., 17, 1409-1419 (2013).
[19] M. G. Pavlović, Lj. J. Pavlović, Morphology and structure of bright electrodeposited metal coatings, Maced. J. Chem. Chem. Eng., 30, 29-43 (2011).

[20] O. B. Ibrahim, Complexes of urea with $\mathrm{Mn}(\mathrm{II}), \mathrm{Fe}(\mathrm{III})$, $\mathrm{Co}(\mathrm{II})$, and $\mathrm{Cu}(\mathrm{II})$ metal ions, Advances in Applied Science Research, 3, 3522-3539 (2012).

[21] S. Surviliene, O. Nivinskiene, A. Cesuniene, A. Selskis, Effect of $\mathrm{Cr}$ (III) solution chemistry on electrodeposition of chromium, J. Appl. Electrochem., 36, 649-654 (2006).

[22] Y. B. Song, D. T. Chin, Current efficiency and polarization behavior of trivalent chromium electrodeposition process, Electrochim. Acta, 48, 349-356 (2002).

[23] X. Hoccart, G. Turrell, A Raman spectroscopic investigation of the dynamics of urea-water complexes, $J$. Chem. Phys., 99, 8498-8503 (1993).

[24] J. Gong, G. Zangari, Electrodeposition and characterization of manganese coatings, J. Electrochem. Soc., 149, C209-C217 (2002).

[25] N. D. Nikolić, G. Branković, M. G. Pavlović, Effect of the electrolysis regime on the structural characteristics of honeycomb-like electrodes, Maced. J. Chem. Chem. Eng., 32, 79-87 (2013).

[26] J. Gong, G. Zangari, Electrodeposition of sacrificial tinmanganese alloy coatings, Mat. Sci. Eng. A, 344, 268 278 (2003)

[27] B. Bozzini, E. Griskonis, A. Fanigliulo, A. Sulcius, Electrodeposition of $\mathrm{Zn}-\mathrm{Mn}$ alloys in the presence of thiocarbamide, Surf. Coat. Technol., 154, 294-303 (2002). 